\title{
The Influence of Attitude on the Treatment of Interdentals in Loanwords: Ill-performed Importations*
}

\author{
Carole Paradis \\ Darlene LaCharité \\ Université Laval. Département de Langues, Linguistique et Traduction \\ Carole.Paradis@1li.ulaval.ca \\ Darlene.Lacharite@1li.ulaval.ca
}

\begin{abstract}
This article treats cross-linguistic variation in the treatment of $/ \theta, \mathrm{\partial} /$ in loanwords. We maintain that the phonological adaptation of $/ \theta, \mathrm{d} /$, cross-linguistically, is to /t, $\mathrm{d} /$, that substitution by /f, $\mathrm{v} /$, which occurs in a few languages, is based on faulty perception of the interdental fricatives, and that adaptation to /s, z/, which notably occurs in Japanese, European French and German, represents a flawed production-based attempt to import interdentals. We suggest that such flawed importation occurs when foreign sounds are difficult to produce but the source language holds sufficient prestige that it is deemed important to do so. This proposal is supported by data from, e.g., English, Greek and Classical Arabic. The treatment of interdentals parallels that of the difficult French phoneme / $3 /$ in loanwords in Fula, which also yields a flawed production-based importation, lending further support to our analysis of $/ \theta, \delta /$ to $/ \mathrm{s}, \mathrm{z} /$ as flawed importations.
\end{abstract}

Keywords: loanword adaptation; interdentals; importations; flawed production-based importations.

* This topic has had a long gestation period. We would like to thank Larry Hyman for lengthy discussions on interdentals with C. Paradis at the time of her sabbatical in 1994 in Berkeley. We are also grateful for questions and comments from the audience at the 2002 North American Phonology Conference at Concordia University, Montreal. Jean-François Prunet was very instrumental in providing pertinent data and references for Semitic languages. This article would not have been possible without the generous help of numerous language consultants and that of our Dutch interviewer Judith Rijpstra, on the project in 2002. We greatly benefited, too, from the work of many Project CoPho research assistants, including Daniel Stoltzfus and Félix Demeules-Trudel. Finally, we are grateful to the editors and two anonymous reviewers for challenging comments and questions as well as helpful suggestions. 


\section{Table of Contents}

\section{Introduction}

2. Interdental replacement

by stops versus fricatives

3. The phonetics of interdentals

4. The role of attitude in speech
5. Another flawed importation: the treatment of French /3/ in Fula

6. Conclusion

References

\section{Introduction}

Attitude plays a crucial role in loanword adaptation notably with respect to the importation of foreign phonemes, i.e. non-adaptations. Importation results from intentional phonetic approximation, whereby a borrower tries to reproduce a foreign phoneme authentically, rather than transform it to a sound found in the inventory of his or her mother tongue (L1). For example, when English speakers pronounce French elan as [elã], they are intentionally mimicking the French pronunciation, with the nasal vowel, which is not a phoneme of English. However, a borrower's attempt at authenticity may not always be successful, as we will subsequently discuss, but when it is, it results in the importation of the L2 phoneme (see Paradis and LaCharité 2008: 94-95 for more discussion).

Importations are fairly commonplace in loanwords. In the Project CoPho loanword database overall, foreign segments are imported $28.7 \%$ of the time (14,391/50,092 phonological cases). ${ }^{1}$ Intensity of the contact between the L1 and the donor language (L2) favors a greater number of importations. Importations reflect a willingness to imitate the sounds of the L2, typically because this language is considered superior, friendly or dynamic.

Here we focus on importation of the interdentals $/ \theta, \circlearrowright /$ drawing mainly on data from English, Greek and Classical Arabic. In loanword adaptation, most languages lacking $/ \theta$, ठ/ adapt them as $/ \mathrm{t}, \mathrm{d} /$ (e.g. English thumbs-up $/ \theta \Lambda \mathrm{mz} \Lambda \mathrm{p} /$ and that's it /ðætsıt/ > Calabrese Italian [tomzop] and Quebec French [datsit]). European French, German and Japanese are notable exceptions to this pattern; they replace interdentals mainly with /s, z/.

1. Project CoPho is concerned with the role of constraints in phonology and is supervised by C. Paradis at Laval University. Statistics are dated August 8, 2009. 
(1) Examples of English / $\theta$, $/$ adapted to /s, z/ in European French, German, Japanese

\begin{tabular}{|c|c|c|c|}
\hline European & $\begin{array}{l}\text { Granny Smith } \\
\text { (apple variety) }\end{array}$ & [gRænismi $\theta$ ] & $>$ [granismis] \\
\hline French & $\begin{array}{l}\text { Big Brother } \\
\text { that is the question }\end{array}$ & 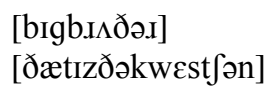 & $\begin{array}{ll}> & \text { [bigbrozœR }] \\
> & {\left[\text { zatizzəkwest } \int \partial n\right]}\end{array}$ \\
\hline German & $\begin{array}{l}\text { Thanksgiving Day } \\
\text { Granny Smith } \\
\text { (apple variety) } \\
\text { Southern }\end{array}$ & 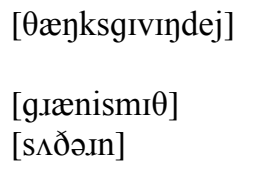 & $\begin{array}{l}>\text { [sæyksgivindej] } \\
>\text { [gRænismis }] \\
>\text { [sauzc.ın] }\end{array}$ \\
\hline Japanese & $\begin{array}{l}\text { bath } \\
\text { marathon } \\
\text { leather }\end{array}$ & $\begin{array}{l}{[\mathrm{bæ \theta} \theta} \\
{[\mathrm{mæ.I \partial \theta an}]} \\
{[\text { leðə. }]}\end{array}$ & $\begin{array}{ll}> & {[\text { basu }]} \\
> & {[\text { marason }]} \\
> & {[\text { reza: }]}\end{array}$ \\
\hline
\end{tabular}

It is not uncommon for a foreign phoneme to be adapted differently according to the L1. For instance, the labiodental /v/, which is prohibited in many languages, is adapted as /b/ in Japanese (e.g. English heavy [hevi] > /hébi:/), as /f/ in Lama (e.g. French valise [valis] 'suitcase' > /fàlísə̀) and as /w/ in Fula (e.g. French avocat [avoka] 'lawyer' $>$ /awoka/). Often this variation is attributable to the L1 phonology (for instance, there is no /f/ in Japanese). Could variable adaptation of $/ \theta, \delta /$ to $/ \mathrm{t}, \mathrm{d} /$ or $/ \mathrm{s}, \mathrm{z} /$ similarly be a case of choosing between phonological possibilities offered by the particular borrowing language? Various researchers, including Hyman (1970), Hancin-Bhatt (1994) and Lombardi (2003) have offered analyses along these lines. In this article we depart from such a view and offer a new perspective that takes into account the influence of attitude towards L2.

The adaptation of $/ \theta, ð /$ is particularly intriguing because it varies between dialects of a language (e.g. European French vs. Quebec French) as well as speech registers, as we will show for Arabic, especially Egyptian Arabic. It is uncommon to see such a variation pattern; usually there is an obvious dominant adaptation within a single language regardless of the dialect or speech register (Paradis and LaCharité 2008:93). For example, English /æ/ is systematically adapted as /a/ in Quebec French from Montreal (369/369 cases, 100\%), Quebec French from Quebec City (399/399 cases, 100\%) and Parisian French (462/462 cases, $100 \%$ ). The figures for other English sounds that do not constitute phonemes in French, such as $/ \mathrm{I} /$ and $/ \Lambda /$, reflect the same pattern in the three French dialects.

We hypothesize that the phonological adaptation of $/ \theta$, $\mathrm{ð} /$, cross-linguistically, is to /t, d/ and that substitution by /f, v/, which occasionally occurs, is based on faulty perception of the interdentals. We refer to the latter as naive phonetic approximation (LaCharité \& Paradis 2005:230). Naïve phonetic approximation does not introduce foreign phonemes into the L1 system. In such cases the borrower simply misperceives the phonetic attributes of L2 phonemes in terms of 
L1 categories (e.g. L2 / $\theta$, ð/ > L1 /f, v/). Naïve phonetic approximation contrasts with intentional phonetic approximation where the borrower correctly perceives the foreign sound and wants to reproduce it in the loanword introduced into L1, because L2 is attractive. Thus intentional phonetic approximation (importation) typically introduces foreign phonemes into L1 (e.g. English job [dzob] > Quebec French [dzob], where foreign [dz] is imported). However, there are some foreign sounds that pose particular production difficulty, in which case the importation may not be well performed and then the target foreign sound fails to be introduced into the L1. We maintain that this is the case when /s, z/ are substituted for $/ \theta, \partial /$; in other words, we view $/ \mathrm{s}, \mathrm{z} /$ as flawed production-based intentional phonetic approximations (importations) of interdentals. These hypotheses are summed up in (2).

(2) Hypotheses regarding the treatment of interdentals:

a. $/ \mathrm{t}, \mathrm{d} /$ are the phonological adaptations of interdentals cross-linguistically (due to [+continuant] delinking) ${ }^{2}$

b. /f, v/ are perception-based naïve phonetic approximations of interdentals;

c. /s, z/ are flawed production-based intentional phonetic approximations (importations) of interdentals.

The flawed production-based importation (hereafter the flawed importation) of interdentals as /s, z/ is due to a conjunction of factors. One is that interdentals are especially difficult to articulate, for both foreign language learners and for child learners of languages with interdentals. Interdentals are iconic English sounds because of their typological rarity and their production difficulty. L2 learners from communities that consider English prestigious are likely to endeavor to mimic these iconic sounds. Their productions may end up in [s, z] simply because of their articulatory difficulty. Another factor is that the acceptability of this flawed importation may be reinforced by knowing that replacement of interdentals by / $\mathrm{t}, \mathrm{d} /$ is stigmatized, being associated with lack of education and social standing (Anisman 1975, Hartford 1978, Zuengler 1988; etc.). In sum, we maintain that phonology motivates the realization of marked $/ \theta$, ð/ as unmarked [-continuant] $/ \mathrm{t}, \mathrm{d} /$, but production difficulties combined with social influences are behind their realization as more marked [+continuant] /s, z/.

The hypotheses in (2) are supported here by five main arguments. The first argument, bringing support for Hypothesis (2a), in particular, is discussed in section 2 , and bears on cross-linguistic distribution. The adaptation of $/ \theta, \mathrm{d} /$ to $/ \mathrm{t}$, d/, whether from English, Greek, Classical Arabic or any other language with

2. Even if $/ \theta, ठ /$ were due to [+distributed] delinking, the adaptation would still be minimal (one changing process). A discussion of the specifics of a particular phonological adaptation is not directly relevant here (we refer the reader to Paradis \& LaCharité 1997 for a more focused discussion of the phonological adaptation of loanwords). 
interdentals, predominates far more than it should if adaptations to /s, z/ were equally principled phonologically. Even those languages famous for realizing the interdentals as /s, $\mathrm{z} /$ did adapt, or continue to sometimes adapt interdentals as $/ \mathrm{t}$, $\mathrm{d} /$. In section 2 we also present a second argument for $(2 \mathrm{a})$ : /t, $\mathrm{d} /$ are substitutes for the English interdentals in many dialects of English, while /s, z/ almost never are. The phonetics of interdentals is taken up in section 3, where we discuss their production difficulty and articulatory proximity to /s, z/ and, in support of Hypothesis (2b), show the perceptual proximity of the interdentals to /f, v/ not /s, $\mathrm{z} /$. This represents the third argument. The fourth argument, supporting Hypothesis (2c) and presented in section 4, is based on the fact that English enjoys particular prestige in France, Germany and Japan. We show that the /s, z/ realizations of foreign interdentals are demonstrably associated with correctness or prestige. This also applies to the adaptations of interdentals from Classical Arabic in different Arabic dialects. Our fifth argument, presented in section 5, is that /s, z/ are not the only flawed importations found in the CoPho loanword database. For example, /z/, which is not permitted in Fula, since voiced fricatives are forbidden, as is the case in Spanish and many other languages, represents the flawed importation of the French fricative /3/. Thus, French agence [azãs] 'agency' and janvier [zãvje] 'January' > Fula [azans] and [zanvije], instead of [asans] and [sanwije] as expected of a purely phonological adaptation. Like the interdentals, the voiced fricative $/ 3 /$ is well known to be typologically uncommon and difficult to acquire and produce. We suggest that flawed importations of foreign segments are likely to occur when a) these segments are difficult to produce, b) they are iconic sounds of L2 and c) the L2 is seen as socially attractive and the attitude of borrowers is positive towards the L2.

\section{Interdental replacement by stops versus fricatives}

\section{1. $/ t$, d/: the normal phonological adaptations of interdentals in loanwords}

Stops are cross-linguistically the most frequent replacement for interdentals, which supports hypothesis ( $2 \mathrm{a}$ ) that $/ \theta, \delta />/ \mathrm{t}, \mathrm{d} /$ is the phonological adaptation. The table in (3) presents a list of languages where the /t, $d /$ adaptation of English interdentals is the norm. 
(3) Adaptations of the English interdentals to stops (/ $\theta, ð />/ t, d /$ ) (non-exhaustive list)

\begin{tabular}{|c|c|c|}
\hline Language & Adaptations & References \\
\hline Calabrese Italian & $/ \theta, \mathrm{d} />/ \mathrm{t}, \mathrm{d} /$ & Savard 2007 \\
\hline $\begin{array}{l}\text { Croatian and Serbo- } \\
\text { Croatian }^{1}\end{array}$ & $/ \theta, ð />/ \mathrm{t}, \mathrm{d} /$ & Velčić 1982; Vilke 1982 \\
\hline $\begin{array}{l}\text { English-based Creoles } \\
\text { (over } 40 \text { languages) }\end{array}$ & $/ \theta, \mathrm{\partial} />/ \mathrm{t}, \mathrm{d} /$ & $\begin{array}{l}\text { Cassidy and LePage 1980; Tinelli 1981; } \\
\text { Wells 1982:204; Holm } 1989\end{array}$ \\
\hline Finnish & $/ \theta />/ t /$ & Orešnik 1982 \\
\hline Hindi & $/ \theta />/ \mathrm{t} / ; / \mathrm{d} / \rightarrow / \mathrm{d} /$ & Consultation with native speakers \\
\hline Hungarian & $/ \theta />/ \mathrm{t} /$ & Jakobs-Németh 1982 \\
\hline Mexican Spanish & $/ \theta, \mathrm{\partial} />/ \mathrm{t}, \mathrm{d} /$ & Fecteau 1998; Bolduc 2001 \\
\hline Norwegian & $/ \theta, \mathrm{\partial} />/ \mathrm{t}, \mathrm{d} /$ & Schmidt 1987 \\
\hline Quebec French & $/ \theta, \mathrm{d} />/ \mathrm{t}, \mathrm{d} /$ & Roy 1992 \\
\hline
\end{tabular}

1. Serbo-Croatian is a general label that includes several different, albeit mutually intelligible, dialects.

Interdentals from English are not the only ones to be adapted mainly to stops. Greek interdentals, too, are predominantly replaced with stops in Macedonian, as spoken in Macedonia. Papazisovka (1966:164) provides several examples, e.g. Greek [Oalasa], [ðifӨcra] and [ðaskalos] > Macedonian [talas] 'sea', [tefter] 'book (specialized)' and [daskal] 'master'. Although some of her examples may be from Ancient Greek, the fact remains that Greek interdentals were adapted to stops, not fricatives. Adaptation to stops also occurs in Macedonian as spoken in Greece; e.g. Greek [ðraxmi] > Greek Macedonian [draxmia] 'drachma'), though Greek interdentals are also often imported in this language (Schmieger 1998:147, 148) as well as in Aromanian (e.g.

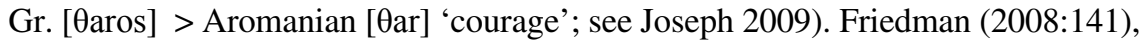
too, reports that: «[...] Aromanian and some Macedonian dialects in contact with Greek in present-day Greek Macedonia have interdental fricatives in Greek loanwords [...]», which Joseph (2009) attributes to familiarity with Greek. Nonetheless, when Greek (and also Albanian) interdentals are adapted, they are adapted to stops. This is typically the case in Slavic languages: «Greek and Albanian fricatives [e.g. $\theta$, б] would be reflected as stops in Slavic, due to Slavic phonological patterns and a presumed relative unfamiliarity with Greek at the time of borrowing» (Joseph 2009:128). According to Henninger (1990:613), the same applies to Bulgarian; e.g. Modern Greek [taksiði] > Bulgarian /taksid/ 'travel, journey'. Papazisovka (1966:159) says that adaptation of the Greek interdentals to stops, as opposed to fricatives, in loans from Greek into Turkish is also the norm; e.g. Gr. [ $\theta \varepsilon m \varepsilon l i u n]$ and [ $\theta$ alasa] > Turkish /temelli/ 'foundation' and /talaz/ '(high) wave'.

Even when the adaptation of interdentals to stops is not the only one in a language, there is no language where the adaptation to /t, $\mathrm{d} /$ is altogether absent. Where the predominant adaptation of $/ \theta, \delta /$ is to /s, $\mathrm{z} /$, that adaptation is never exclusive; 
there are always cases where interdentals also adapt to /t, $\mathrm{d} / \mathrm{as}$ in the mixed cases in the table in (4).

(4) Mixed cases of adaptation of interdentals

\begin{tabular}{|c|c|c|}
\hline Language & Adaptations & References \\
\hline Amharic & Arabic (Ar.) $/ \theta, \partial />/ \mathrm{t}, \mathrm{d} /$ or $/ \mathrm{s}, \mathrm{z} /$ & Leslau1990 \\
\hline $\begin{array}{l}\text { Arabic dialects } \\
\text { lacking interdentals }\end{array}$ & $\begin{array}{l}\text { Classical Arabic }(\mathrm{CA}) / \theta, \partial />/ \mathrm{t}, \mathrm{d} / \\
\text { in colloquial speech; in CA words } \\
\text { with literary status, } / \theta, \circlearrowright />/ \mathrm{s}, \mathrm{z} /\end{array}$ & $\begin{array}{l}\text { Cantineau 1960; } \\
\text { Ferguson 1978; } \\
\text { Carter } 2001\end{array}$ \\
\hline Aramaic (modern) & Ar. $/ \theta$, ठ/ > /t, d/ or $/ \mathrm{s}, \mathrm{z} /$ & Ferguson 1978 \\
\hline Czech & $\begin{array}{l}\text { Eng. } / \theta />/ \mathrm{s}, \mathrm{t} / \text { (or } / \mathrm{tx} / \text { from orthog- } \\
\text { raphy); /ð/ / /z, d/ (or /dh/ from } \\
\text { orthography) }\end{array}$ & Poldauf 1982 \\
\hline
\end{tabular}

Danish

Generally imported; Eng. / $\theta$, ठ/ >/t, Sørensen 1982; consulta$\mathrm{d} / ; / \mathrm{s}, \mathrm{z} /$ occur in a few words tion with native speakers

Dutch Generally imported; otherwise Eng. Gerritsen 1982; consulta$/ \theta, ठ />/ \mathrm{t}, \mathrm{d} / ; / \mathrm{s}, \mathrm{z} /$ occur in a few tion with native speakers words

European French Imported or Eng. / $\theta$, ठ/ > /s, z/ in Fouché 1959; consultaeducated speech. Previously, and in tion with native speakers less educated speech: $/ \theta, \mathrm{\partial} />/ \mathrm{t}, \mathrm{d} /$; stops are still used to adapt some new borrowings.

Fula of Guinea and Ar. $/ \theta />/ \mathrm{s}, \mathrm{t} / ; / \circlearrowright />/ \mathrm{d} 3 /$ (except in Labatut 1983; Diallo North Cameroon formal speech, where /ð/ >/z/) 1992

Fula of Sudan Imported or Ar. $/ \theta$, d/ >/t, d/ or /s, Abu-Manga 1986 $\mathrm{z} /$

Ge'ez

Ar. / $\theta$, ð/ > /t, d/ or /s, z/ (probably Leslau 1990 because of CA)

German Importation or adaptation Eng. $/ \theta, \mathrm{d} />/ \mathrm{s}, \mathrm{z} / ; / \mathrm{t}, \mathrm{d} /$ occur in a few words)

Hooke and Rowell 1982; consultation with native speakers

$\begin{array}{ll}\text { Gurage } & \text { Ar. } / \theta />/ \mathrm{t} / ; / ð />/ \mathrm{d} / \text { or } / \mathrm{z} / \\ \text { Harari } & \text { Ar. } / \theta />/ \mathrm{s}, \mathrm{t} / ; / \mathrm{d} / \rightarrow / \mathrm{z} / \\ \text { Japanese } & \text { Eng. } / \theta, \mathrm{\delta} />/ \mathrm{s}, \mathrm{z} / \text { but also } / \mathrm{t}, \mathrm{d} /\end{array}$

Leslau1990

Leslau 1990

Kenworthy 1987; Goulet 2001; consultation with native speakers

Tigré

Ar. $/ \theta />/ \mathrm{t} /($ sometimes /s/);/ / / $\quad$ Leslau 1990 $/ \mathrm{d} /$ or $/ \mathrm{z} /$

Tigrinya

Ar. $/ \theta />/ \mathrm{s}, \mathrm{t} / ; / \mathrm{d} />/ \mathrm{z}, \mathrm{d} /$ Leslau 1990 
Our research suggests that all those languages that replace the interdentals with the fricatives /s, z/ also have the /t, d/ adaptation, sometimes as their main one. For example, in Dutch, Danish and German, the English interdentals are usually imported, either authentically $(/ \theta, \partial /)$ or imperfectly $(/ \mathrm{s}, \mathrm{z} /)$. However, when they are not imported, they are adapted mainly to $/ \mathrm{t}, \mathrm{d} /$. This occurs typically in the speech of older people (e.g. English in the middle of nowhere [InðəmIdələvnowe.I]

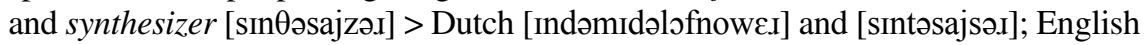

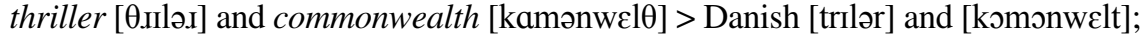
English thriller and synthesizer $>$ German [trilər] and [sintəsajzəx]). Although the realization /s, z/ is pervasive in German, it is confined to only a few items in Dutch and Danish (e.g. English happy birthday [hæpibə.Өdej] or Granny Smith [g.ænismi $\theta$ ] > Dutch [hæpibə.sdej] and [gıænismis]).

Even in the languages where the main realization of the interdentals is /s, z/, adaptations to $/ \mathrm{t}, \mathrm{d} /$ are attested. This is true of European French and Japanese, for example. Fouché (1959:369) reports that «Autrefois le th anglais se prononçait [t] en français. Mais aujourd'hui $[\mathrm{t}]$ tend à céder la place à $[\theta]$ » ('Formerly the English th was pronounced [t] in French. But today [t] tends to give way to [ $\left.\theta]^{\prime}\right)$. He adds that adaptation to $/ \mathrm{t}, \mathrm{d} /$ is passé, and recommends pronouncing the interdentals authentically. This suggests, as we will maintain, that when French borrowers realize the English interdentals as /s, z/, they are trying, but failing, to pronounce the interdentals authentically, not phonologically replace them with acceptable French phonemes (i.e. /s, z/). A flawed importation such as /s, z/ can become institutionalized if it is taught in schools, as is the case in France for interdentals (see also Hyman 1970:11). Phonological adaptation of the interdentals to /t, d/ still occurs in the speech of older or less educated speakers according to several French speakers that we consulted and our own observations. It is also used by young speakers in some new English borrowings such as thong, widely pronounced [tõg] in France. Nor is the adaptation of the interdentals to $/ \mathrm{t}, \mathrm{d} /$ rare in Japanese, despite the fact that /s, z/ are the usual replacements for the English interdentals. Examples of stop replacements in Japanese are given in (5).

(5) Examples of English interdentals adapted to /t, d/ in Japanese

\begin{tabular}{|c|c|c|c|}
\hline & English & & Japanese \\
\hline thnic & [عंnik] & $>$ & [etiniku] \\
\hline P & {$[\theta \Lambda \mathrm{mz} \wedge \mathrm{p}]$} & $>$ & [tamap] \\
\hline & 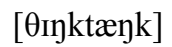 & & tinktan \\
\hline
\end{tabular}

To the best of our knowledge, there is no language where /s, z/ is the only adaptation. As indicated above, the reverse is not true - we often find languages where /t, $d$ / is the only adaptation for interdentals either from English or Greek (e.g. Quebec French). The prevalence of the adaptation of interdentals to $/ t, d /$ and the fact that it occurs, sometimes predominantly, even in languages where substitution by /s, $\mathrm{z} /$ occurs, constitute strong arguments for interpreting $/ \theta, \partial />/ \mathrm{t}, \mathrm{d} /$ as the phonological adaptation. 
A possible objection to this interpretation could be that orthography influences the $/ t, d /$ adaptation, since the digraph $<$ th $>$ usually represents $/ t /$ in French, as it can in other languages, including English (e.g. Thomas) and German (e.g. Thermische 'thermal'). However, orthography cannot explain the adaptation of the English voiced interdental / $/$ / to $/ \mathrm{d} /$, not $/ \mathrm{t} /$, because both interdentals are written with the digraph $<$ th $>$ in English (e.g. English on the rocks $>$ Parisian and Quebec French [ondərok] not *[ontərok]. ${ }^{3}$ The same applies to the borrowing (Marx) brothers [br^ðərz] in Japanese, where it is often pronounced [brada:z] not *[brata:z].

Another possible objection to the analysis that we offer is that the choice of adaptation to /s, z/ or to /t, d/ is due to phonetically different input. Regional variation in the precise realization of English interdentals has been noted; MacKay (1987:95) indicates that in some regions pronunciation is dental while in others it is interdental. It has been suggested that $/ \theta, \mathrm{\partial} /$ are dental in British English but interdental in American English (Ladefoged and Maddieson 1996:143). Could it be that French, German and Japanese have been exposed to the British dental pronunciation while those languages that adapt to /t, $\mathrm{d} /$ have been influenced by the American interdental pronunciation? This is unlikely. First, the variability does not divide perfectly along dialect lines; some American speakers pronounce $/ \theta$, ð/ dentally, and some British speakers pronounce them interdentally (Ladefoged and Maddieson 1996:143). Second, it has been very widely documented that, as for most other countries, the prevailing English influence on France, Germany and Japan has been American English since WWII. Third, how could the different input view account for variable adaptation of interdentals (either from English or Classical Arabic) within a single language, such as in the cases given in (4)? We conclude that the variable input hypothesis is tenuous.

A third possible objection, following from the analysis of Brannen (2002) is that differential interpretation of the interdentals is due to L1-influenced perception, though it is important to note that Brannen's conclusions are based on a discrimination task by advanced L2 learners, not on loanword adaptation. Under this perceptual approach, which Picard (2002) favors over a phonological one, the particular adaptation strategy would depend on a language-specific configuration of phonetic features in which one phonetic feature can mute another, making either $/ \mathrm{s} /$ or $/ \mathrm{t} / \mathrm{a}$ better perceptual match for $/ \theta /$. For example, in European French (EF), the feature dental could mute strident, making /s/ ([s] ) a better perceptual match for $/ \theta /$ than $/ t /$. However, we have doubts about some basic phonetic assumptions on which Brennan's analysis crucially depends, as well as about the generalizability of her conclusions. For example, differential substitution in Quebec French (QF) versus EF depends on /s/ being consistently realized as a dental in EF. Yet Dart (1991), Brannen's source of information about EF articulation, shows that EF speakers produce a dental sibilant less than half the time. In fact, test results for $\mathrm{EF}$ and QF speakers were not significantly different and Brennan herself concedes (p. 36) «...EF and QF have the same phonetic representations for the segments of interest [notably [s] and [ $\theta]]$.» In any case, her approach would not explain variable

3. In Parisian French, the pronunciation [эnżrok] is also well attested. 
adaption of the interdental fricatives in the two dialects of French and it could not explain the fact that the interdentals were previously systematically adapted to $/ \mathrm{t}$, $\mathrm{d} / \mathrm{in} \mathrm{EF}$, as mentioned earlier in this section.

Now for Japanese: Brannen's results show that Japanese listeners are unable to reliably distinguish between [s] and [ $\theta$ ]. The results in this case are statistically significant, with a $26 \%$ error rate. So the fact that the sibilant tested in her L2 perception experiment is dental, which is claimed to mitigate stridency and be the source of the [s] - [ $\theta$ ] confusion, could be used as a perception-based explanation for the adaptation of English interdental $/ \theta /$ to $/ \mathrm{s} /$ in English loanwords in Japanese. However, Japanese /s/ is realized not as a dental but a laminal mellow fricative. Vance (1987:20), the source of information upon which Brannen relies, calls Japanese /s, z/ «alveolar fricatives...that are essentially identical to their English counterparts.» Moreover, according to the description provided by Vance (1987:18-19), Japanese /t/ is realized in a way that is phonetically much closer to French than to English, calling into question the idea that Japanese /s/ is a better perceptual match for $/ \theta /$ than is Japanese /t/. In short, the crucial presence or absence of certain dampening phonetic features is a debatable explanation for the replacement of interdentals by /s, $\mathrm{z} /$ instead of $/ \mathrm{t}, \mathrm{d} /$.

Another problem is that the perceptual explanation offered by Brannen would not apply to German, which also adapts $/ \theta$, ठ/ mainly to /s, z/, at least in loanword adaptation. She does not discuss German, but German's consonant inventory includes both strident and mellow fricatives. Therefore, German speakers would not be expected to have the perceptual problems exhibited by the Japanese speakers and thus would not be likely to replace interdentals with /s, z/ on perceptual grounds. Finally, as will be shown in 2.2, interdentals become stops in many English dialects where stops are alveolar, not just those in which they are realized as dentals. It would also be hard to explain cases of substitution that introduce phonemes not in the native inventory, as in the case of French / $/$ / which yields non-native /z/ in Fula, to be discussed in 5. In sum, the perceptual explanation, which presupposes a direct link between L1 and L2 phonetic features, appears to us to be unsatisfactory.

\subsection{Interdental replacement by stops in English dialects}

Although many English dialects are widely acknowledged to synchronically substitute various sounds for $/ \theta$, $\delta$, replacement by stops is the most frequent substitution. However, rarely are the interdentals replaced all the time, an important indicator that it is a synchronic process; few, if any, dialects of English lack interdentals altogether. The substitution of interdentals is widely regarded to be nonstandard or even substandard. For example, of Jamaican English, Canepari (2010:567) remarks that «the merger of $/ \theta$, $\delta /$ with [alveolar stops] normally occurs only at the lowest [social] levels...» In describing its occurrence in the American South, Canepari (2010:340) says that it is typical of «broader [i.e. non-standard] accents». Where interdental substitution is a defining characteristic of the dialect, speakers are often aware that they do it and that it is «frowned upon» and /or possibly seen as somewhat rebellious; it can be the linguistic equivalent of thumbing one's nose 
at authority. According to Eckert (2000:221) the stopped variant is a marker of (desired) emphasis and toughness in many urban areas of the United States due to its association with certain immigrant groups (e.g. Italian, Polish, Spanish). Canepari's statements may strike us as prescriptive rhetoric, but in recording various pronunciations as departures from 'neutral [standard] pronunciation' Canepari seeks to reflect the value that the speaker communities put on various pronunciations (see also remarks by Ferguson 1978:423 on attitudes toward interdental replacement by stops). Canepari reports that the standard pronunciation, including that of interdentals, is an ideal for a speaker community, but he also adds that it is «...actually used by [only] about $3 \%$ of the total speakers of any language...» (p. 16). In other words, interdental replacement likely occurs far more than speakers - particularly those who consider themselves to be speakers of the standard form of the language - are willing to admit, even to themselves.

The dialectal substitutions for $/ \theta, \delta /$ most commonly cited are [t, d] (or [t, d] and [f, v]. However, there is a marked asymmetry in interdental substitution across various dialects of English; as in loanword adaptation, stop replacement heavily predominates in dialectal substitution. Canepari's (2010) very detailed description of the pronunciation of well over a hundred English varieties around the world records the substitution of interdentals in approximately three dozen dialects of English. In more than two dozen dialects (e.g. Newfoundland English, Chicano English, Metropolitan North, New York City, Eastern Eire, Jamaican English, to name just a few mentioned by Canepari) the substitution is to [t, d] (or [t, d]). This feature of several American English dialects, e.g. southern, Brooklyn, Detroit, Philadelphia, has long been the object of considerable sociolinguistic interest (e.g. Labov 1966, Wolfram 1969, Cofer 1972: 215-251 cited in Ferguson 1978:422-423; Wolfram and Schilling-Estes 1998, etc.).

In contrast, only a handful of English dialects, most notably Black American English and Cockney, substitute [f, v] for $/ \theta, \partial /$. Of those, some, such as Black American and London Jamaican are noted to substitute stops as well, sometimes mainly. The net result is that [f, v] replacement really predominates in only a couple of dialects of English. Canepari (2010) also indicates a smattering of other dialectal replacements for $/ \theta, \partial /$. In some Scottish dialects, for example, $/ \theta /$ may be replaced by $[\mathrm{h}]$. In the Hebrides and the dialect called 'Basic' Black speech of South Africa $/ \theta, ð /$ may be replaced by [s, z], though stop replacement is also noted to occur in the dialect. In sum, the substitution of interdental fricatives by stops across different dialects of English is decidedly predominant, which parallels what we find in loanword adaptation and brings indirect support to the view that the phonological adaptation of interdentals is to $/ \mathrm{t}, \mathrm{d} /$.

\section{The phonetics of interdentals}

\subsection{The production difficulty of $/ \theta, \partial /$ and articulatory closeness to $/ s, z /$}

Interdental fricatives are cross-linguistically rare; in the UPSID database, only $18 / 317$ (5.7\%) languages have $/ \theta /$ and 21/317 (6.6\%) have its voiced counterpart 
/ð/, Maddieson 1984). The cross-linguistic rarity of interdentals is partly due to the difficulty in producing them (Maddieson 1997:637), which is reflected in the fact that they are among the last phonemes mastered by children acquiring an L1 with interdentals (see, e.g., Bowen 1998 and Dodd et al. 2003 who provide an overview of the results of several studies on the acquisition of interdentals).

The fact that interdentals are relatively difficult phonemes to pronounce may explain why they are inaccurately reproduced in loanwords, but what accounts for their substitution by /s, z/ instead of perceptually closer /f, v/? The answer is that $/ \theta$, ठ/ and /s, z/ are articulatorily close (MacKay 1987:96, Rogers 2000:56). A strong piece of evidence for this claim is that children who misarticulate /s, $\mathrm{z} /$ - somewhat paradoxically, considering the late acquisition of the interdental phonemes - usually substitute [ $\theta$, ð] (e.g. Winitz 1969, Smit et al. 1990, Mowrer and Sundstrom 1988 Rvachew and Jamieson 1989). MacKay (1987:96) notes that /s, z/ are produced «with the tongue slightly grooved» and that «Failure to form the groove is responsible for certain types of lisp.» The production of $[\theta, \partial]$ instead of target /s, z/ occurs among children in other languages, including French (where it is referred to as parler sur le bout de la langue 'to speak on the tip of the tongue') and German (where the colloquial term is lispeln) that do not have interdentals in their phoneme inventories. Thus, the substitution of /s, z/ for the interdental fricatives is much more likely production related, rather than being rooted in perceptual confusion between $/ \theta, \delta /$ and /s, $\mathrm{z} /$ (this issue will be extensively discussed in the next section).

The difficulty in correctly producing interdentals is widely observed among L2 learners as well. For example, in addition to being problematic for French, Japanese, and German learners of English, Kenworthy (1987) reports that they are problematic phonemes for speakers of Cantonese, Hokkien and Italian; Gonet and Pietron (2006) and Lukaszewicz (2009) report the particular difficulty that Polish learners of English have in producing them; Chang (2004) and Fu (2010) discuss the difficulty $/ \theta /$ poses for Taiwanese learners.

In the course of L2 learning, / $\theta /$ is often replaced by /s/. For example, in a study on the acquisition of English interdentals by Polish learners Lukaszewicz (2009) found that learners produced /s/ in as many as 30\% of the cases, though from a perception point of view, the interdentals were most often confused with /f, v/. She further found that perception was far ahead of production, meaning that well after learners could correctly perceive the English interdental fricatives, they were still unable to correctly produce them reliably. Fu's (2010) study of the perception and production of English interdentals by Taiwanese learners also showed an asymmetry between perception and production. While learners erroneously produced $/ \theta /$ as $/ \mathrm{s} /$, they never misperceived $/ \theta /$ as $/ \mathrm{s} /$. Chang (2004) found that Taiwanese learners produced $/ \mathrm{s} /$ as a substitute for $/ \theta /$ most of the time. Moreover, the learners in that study explicitly said that they found $/ \theta /$ difficult to produce and that they considered /s/ the best substitute (/t/ and /f/ were considered much less desirable substitutes). Rau et al. (2009) show that although learners of English from Taiwan and Mainland China produce a variety of substitutes for $/ \theta /$, both groups clearly rate /s/ as the most acceptable one; in other words, «if you can't get it absolutely 
correct, try to settle for $/ \mathrm{s} / \gg$. This argues in favor of the flawed production-based importation hypothesis (2c). The phonemes targeted are $/ \theta, \mathrm{\partial} /$, but since L2 speakers cannot produce them correctly they select mainly /s, $\mathrm{z} /$ as a compromise.

\subsection{Perceptual confusion with /f, $v /$}

In support of hypothesis (2b), we will show in this section that the phonetic literature is clear that /f, v/, not /s, z/, are the closest perceptual matches for $/ \theta, \partial /$. The confusion matrix presented in (6) reveals several things pertinent to this assertion.

(6) Confusion figures from greatest to least (extracted from the confusion matrix of Miller and Nicely 1955, as presented in MacKay 1987:287):

\begin{tabular}{|c|c|c|c|}
\hline Spoken & Heard & Occurrence rate & Percent \\
\hline \multirow[t]{7}{*}{$\theta$} & $\theta$ & $114 / 232$ & $49.1 \%$ \\
\hline & $f$ & $85 / 232$ & $36.6 \%$ \\
\hline & $\mathrm{p}$ & $11 / 232$ & $4.7 \%$ \\
\hline & $\mathrm{s}$ & $10 / 232$ & $4.3 \%$ \\
\hline & $\mathrm{t}$ & $6 / 232$ & $2.6 \%$ \\
\hline & $\mathrm{k}$ & $4 / 232$ & $1.7 \%$ \\
\hline & $\mathrm{v}$ & $2 / 232$ & $0.9 \%$ \\
\hline \multirow[t]{5}{*}{ д } & ð & $105 / 204$ & $51.5 \%$ \\
\hline & $\mathrm{v}$ & $64 / 204$ & $31.4 \%$ \\
\hline & $\mathrm{z}$ & $18 / 204$ & $8.9 \%$ \\
\hline & g & $10 / 204$ & $4.9 \%$ \\
\hline & b & $7 / 204$ & $3.4 \%$ \\
\hline \multirow[t]{7}{*}{$f$} & f & $199 / 264$ & $75.38 \%$ \\
\hline & $\theta$ & $46 / 264$ & $17.42 \%$ \\
\hline & $\mathrm{p}$ & $4 / 264$ & $1.5 \%$ \\
\hline & $\mathrm{s}$ & $4 / 264$ & $1.5 \%$ \\
\hline & $\mathrm{t}$ & $3 / 264$ & $1.1 \%$ \\
\hline & ə & $1 / 264$ & $0.4 \%$ \\
\hline & $\mathrm{b}$ & $1 / 264$ & $0.4 \%$ \\
\hline \multirow[t]{8}{*}{$\mathrm{v}$} & $\mathrm{v}$ & $177 / 239$ & $75 \%$ \\
\hline & ð & $29 / 236$ & $12.3 \%$ \\
\hline & $\mathrm{b}$ & $19 / 236$ & $8.1 \%$ \\
\hline & $\mathrm{z}$ & $4 / 236$ & $1.7 \%$ \\
\hline & $\mathrm{f}$ & $3 / 236$ & $1.3 \%$ \\
\hline & g & $2 / 236$ & $0.8 \%$ \\
\hline & $\theta$ & $1 / 236$ & $0.4 \%$ \\
\hline & 3 & $1 / 236$ & $0.4 \%$ \\
\hline
\end{tabular}


The matrix indicates that native English speakers misperceive $/ \theta$, ð/ about half the time, most frequently mishearing them as $/ \mathrm{f}, \mathrm{v} /$. In contrast, confusion of $/ \theta$, $ð /$ with $/ \mathrm{s}, \mathrm{z} /$ is rare. Confusion of $/ \theta /$ with $/ \mathrm{t} / \mathrm{is}$ rarer still and confusion of $/ ð /$ and /d/ does not occur in the data on which the matrix is based. The perception of /f, $\mathrm{v} /$ is much more robust than perception of the interdentals - they are correctly perceived about three-quarters of the time - but when /f, v/ are misperceived, they are most often confused with $/ \theta, \mathrm{d} /$, very seldom with $/ \mathrm{s}, \mathrm{z} / \mathrm{or} / \mathrm{t}, \mathrm{d} /$. The matrix also shows that $/ \theta, \mathrm{\delta} /$ are misperceived as /f, v/ at over twice the rate that /f, v/ are misperceived as $/ \theta, \partial /$, a perceptual bias that speaks to the comparative markedness of the interdental fricatives.

If we consider the type of sound spectrum for the fricatives, there are more similarities between the labiodentals and the interdentals than there are between the interdentals and the coronal sibilants, as shown in (7).

(7) Similarities and differences in spectrum type (Pickett 1999:140):

\begin{tabular}{|c|c|c|c|}
\hline Fricative cues & /f, v/ & $/ \theta$, ठ/ & $/ \mathrm{s}, \mathrm{z} /$ \\
\hline $\begin{array}{l}\text { - Frication } \\
\text { (stronger for } \\
\text { voiceless than } \\
\text { for voiced) }\end{array}$ & $\begin{array}{l}\text { - Diffuse } \\
\text { spectrum, } \\
\text { strongest } \\
\text { around } 5-7 \mathrm{KHz}\end{array}$ & $\begin{array}{l}\text { - Diffuse } \\
\text { spectrum, } \\
\text { strongest in } \\
\text { frequencies } \\
\text { around } 5 \mathrm{KHz} \\
\text { and above }\end{array}$ & $\begin{array}{l}\text { - Strong } \\
\text { spectrum at } \\
4 \mathrm{KHz} \text { and } \\
\text { above }\end{array}$ \\
\hline $\begin{aligned} &- \text { Vowel } \\
& \text { transitions }\end{aligned}$ & - Upward F2 & - Downward F2 & $\begin{array}{l}\text { - Often no vowel } \\
\text { transitions }\end{array}$ \\
\hline
\end{tabular}

In terms of amplitude, the interdentals are also closer to the labiodentals than

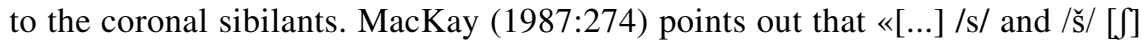
appear as the loudest; /f/ is considerably less loud; and /ð/ shows up as being quite weak». According to relative intensity ratings, $/ \mathrm{s} /$ and $/ \theta /$ are at opposite ends of the spectrum, as shown in (8).

(8) Relative intensity of some consonants (Ball and Rahilly 1999:161):

\begin{tabular}{|c|c|}
\hline Sounds in order of decreasing intensity & Relative Intensity $(\mathrm{dB})$ \\
\hline $\mathrm{s}$ & 12 \\
\hline $\mathrm{z}$ & 12 \\
\hline $\mathrm{t}$ & 11 \\
\hline $\mathrm{v}$ & 10 \\
\hline $\mathrm{d}$ & 10 \\
\hline $\mathrm{d}$ & 8 \\
\hline $\mathrm{f}$ & 7 \\
\hline$\theta$ & 0 (i.e. threshold of audibility) \\
\hline
\end{tabular}


In sum, by a variety of acoustic or perceptual criteria interdentals are closer to /f, $\mathrm{v} /$ than they are to $/ \mathrm{s}, \mathrm{z} /{ }^{4}$ Thus the replacement of $/ \theta, \mathrm{\partial} /$ by /s, $\mathrm{z} /$ in loanwords is unlikely due to perceptual confusion. In the next section we maintain that it is, instead, due to sociolinguistic factors, notably L2's attractiveness, motivating the - sometimes ill-performed - importation of foreign phonemes.

\section{The role of attitude in speech}

\subsection{Identity defined through L1 pronunciation}

Speech style is socially determined and is manifested particularly in pronunciation. Speakers use certain aspects of pronunciation «to express their identity or to lay claim to other identities...» (Bell 2006:99; see also Dyer 2006:101). For example, as previously noted, a marker of Newfoundland English, among other dialects, is the replacement of interdental fricatives by stops, so words such as thick $/ \theta \mathrm{rk} /$ and the /ठə/ are pronounced [tık] and [də], respectively. ${ }^{5}$ Attitude plays a major role in the selection and manipulation of pronunciation features used to express speech style. For example, if one values identity as a speaker of Newfoundland English, then replacing $/ \theta, \delta /$ with $[\mathrm{t}, \mathrm{d}]$ is a more prevalent feature of speech; whereas if one seeks to distance oneself from that identity, either generally or in a specific speech situation, then such replacement is less prevalent, or even non-existent. Speakers judge language - most notably its pronunciation - along dimensions of superiority, social attractiveness and dynamism (Garrett 2006:117, 118). These dimensions do not necessarily place the same value on a given dialect feature in all situations or with all audiences. For example, comedians from Newfoundland often exhibit fricative stopping in their comedy routines, which arguably enhances their social attractiveness, dynamism and audience appeal. Listeners are less likely, however, to consider such dialect features as signs of prestige, intelligence or competence in other discourse situations. The more concern the speaker and listener have for these attributes, the higher will be the value placed on standard pronunciations and the closer to the standard form of the language pronunciation will be (see, for example, Milroy 2006 on the relationship between language attitudes and the standard language).

4. One reviewer commented that the voiceless and voiced interdentals are not necessarily each perceptually equidistant from /f, v/, respectively, and concluded that they should not be treated together. We disagree with this view on the basis of the evidence presented in this section, that is both interdentals pattern with /f, v/ perceptually. Both interdentals also pattern together in loanword studies, where they yield /t, d/ (if they are adapted) or /s, z/ (if they are imperfectly imported), despite the lack of perceptual equidistance. This is why we strongly recommend that loanword adaptation not be confused with language acquisition, where the treatment of foreign sounds is typically variable, especially at the beginning stages of L2 learning where variation is pervasive and shows a greater range of substitutes for L2 sounds.

5. This phenomenon and others in Newfoundland English have been extensively studied; for more information and references see Childs et al. (2010). 


\subsection{Identity defined through L2 pronunciation}

L2 is not exempt from concerns for speech style, identity and listeners' judgments. Indeed, as Haugen (1956) and Grosjean (1982) observed years ago, a foreign language as a whole can be considered prestigious and «...whenever two languages are in contact, one is usually considered more prestigious» (Grosjean 1982:120), though as in the case of dialect features, value may change with the situation or the audience. For instance, one language may be considered better for expressing emotion or for conversing with friends, but another preferable for work-related discussions or conversing with superiors.

Although L2 speakers may be less able to manipulate speech features with the same degree of nuance «the same phenomenon operates between as well as within languages» (Bell 2006:99). With respect to speech style, there is a widely observed link between target-like pronunciation and formality versus informality. Dowd, Zuengler \& Berkowitz (1990) sum up the finding of a variety of studies that the highest proportion of target-like variants occur in the most formal language tasks, while the lowest proportion occurs in free speech, the most casual style. They further note that some target L2 sounds, including the interdentals, are more affected by style shift than others. Moreover, foreign sounds are not necessarily mastered in all word or syllable positions, or all phonotactic contexts at once (Trofimovich et al. 2007).

Studies by Gatbonton et al. (2005), Gatbonton and Trofimovich (2008) and Segalowicz et al. (2008) have linked ethnic identity and pronunciation accuracy in L2. All three studies focus on Quebec French (QF) learners' pronunciation of L2 English. Gatbonton et al. (2005:489) found that «learners treat their peers' L2 accent as an indicator of these peers' degree of ethnic affiliation»; in this case, because of the historical sociopolitical tension between Anglophones and Francophones in Quebec, a higher value was placed on having a stronger QF accent, rather than on sounding more English-like. This was confirmed by results from Gatbonton and Trofimovich (2008), whose study also relates a stronger QF accent to a desire to maintain social and political distance from Anglophones. The study by Segalowicz et al. (2008) specifically investigated QF learners' pronunciation of English /ð/, finding that when QF speakers had a stronger ethnic affiliation with Quebec and a greater desire to distance themselves ethnically from Anglophones, they were more likely to replace English /ð/ by /d/.

Paradis, Lebel and LaCharité (1993) and Paradis and LaCharité (1997, 2008) found that importation rates correlate with levels of community bilingualism in the corpora of Project CoPho; the lower the percentage of bilinguals in a community, the lower the rate of foreign phoneme importation, and vice versa. Harriott and Cichocki (1993:104), too, found that «Listeners with high [proficiency] English (L2) are more lenient towards (and accepting of) L2 pronunciations of a loanword than are low L2 proficient listeners.» In this perspective, the degree of both individual and community-wide bilingualism have an influence on the pronunciation of L2 phonemes. However these are not the only criteria. Attitude also plays a crucial role with respect to the importation of foreign phonemes. Early studies (e.g. Weinreich 1968) tell us that if the L2 is held in high regard and is not seen as threatening, L1 
speakers may have a higher tolerance for L2 sounds and structures, whereas purist attitudes toward the L1, or rebellious ones toward L2, among other factors, favor their adaptation. The attitude of France towards English, where bilingualism is an individual concern and as such is not really threatening, is more positive than that of Quebec, where bilingualism is institutional / political and imposed. The situation in Quebec is what Mackey (1992:38-39) would refer to as «linguism», or even «linguicism». Therefore QF speakers have historically been less willing than European French (EF) speakers to import marked English segments such as interdentals, because of the iconic English nature of these phonemes. We suggest that this accounts for the fact that, when they are not correctly imported, interdentals are realized as /t, d/ in QF and as /s, z/ in EF.

\subsection{The prestige of English in France, Germany and Japan}

The particular prestige of English in France, Germany and Japan has been widely observed and abundantly documented and often referred to as anglomania. We maintain that anglomania in France, Germany and Japan, where bilingualism is seen as a personal advantage rather than as part of a political agenda, accounts for the willingness of speakers from these countries to import English hallmark consonants $/ \theta, \delta /$, albeit sometimes, or even often, inaccurately (i.e. as /s, z/). English in France, Germany and Japan is specifically promoted by the media, notably through advertising, music and cinema, which actively associates English with modernity, hipness and sophistication. Piller (2003) considers advertising to be a major site of language contact between English and whole communities of nonEnglish speakers and she views it to be a notable source of loanwords. She says (p. 170) «English has largely become a non-national language and has been appropriated by advertisers in non-English-speaking countries to index a social stereotype. English has become the language of modernity, progress and globalization» (see also Kelly-Homes 2000:67).

As predicted by the economic dominance of the United States, it is American English in particular that has dominated advertising, music and cinema. This is not to say that the media is not adept at nuancing their use of English to enhance product appeal in a local market and, according to Bhatia (2006:607), «Due to the overt phonetic component, the ethno-cultural stereotypes are marked often by means of world English accents.» While non-standard accents may be used to establish a certain rapport with a particular audience, the overall effect of non-standard accents is to enforce negative stereotypes. Speaking of the power and ideology of English accents, Martin (2006:586) recounts the results of a study by Pandey (1997) showing that the use of non-standard accents underscores their speakers' socio-economic powerlessness and possibly their moral inferiority. The title of a book by Bouchard (1999), On n'emprunte qu'aux riches: la valeur sociolinguistique et symbolique des emprunts [We only borrow from rich people: the sociolinguistic and symbolic value of borrowings], is quite revealing in this respect.

Although anglomania has been denounced for centuries in France (e.g. Étiemble 1973; Boly 1974), it is still alive and well. According to Voirol's (1993) book 
Anglicismes et anglomanie [anglicisms and anglomania], since 1940 the flow of loanwords from one language to the other has been clearly in favor of English words being borrowed into French. The French are so fond of English that they frequently create new words from English stems and suffixes such as footing 'a walk', pressing 'a dry cleaner', forcing 'harassing', etc. Tournier (1998) characterizes many of these terms as «snobbisms». Johnny Halliday, the famous French rock star even changed his original name, Jean-Philippe Smet, to the English name that he is known by, to sound more attractive to his French audience. As for interdentals, their mastery is seen as prestigious for French speakers, just as the ability to correctly perform the French liaison is for English speakers who speak French.

Martin $(1998,1999)$ shows that in a study of over 4,000 French television advertisements, English was widely used, particularly, but certainly not exclusively, in the advertising of cosmetics and beauty products. Martin (2002:8) puts the figures in another perspective, reporting «over $30 \%$ of the television commercials included in the corpus featured some form of English.» Martin (2008) shows that the incursion of English into French continues unabated, despite legislation intended to curb the use of languages other than French. In at least the major urban centres of France, English popular music is pervasive; it is routinely played as background music in shops, bars and restaurants and it features heavily on French radio (Martin 2006:16).

English is also widely used in Germany. With respect to the use of English in advertising Piller (2003:174) states that «Germany...can easily be regarded as the most Americanized of European countries...In a corpus of 658 commercials broadcast in 1999, 73.4\% made use of a language other than German... and that language was English in the majority of cases.» She further states that English is used to promote a social stereotype. The high incidence of American English in German advertising was earlier noted by Hilgendorf (1996), who also tells us that Germans have easy access to English language television shows, including daily broadcasts such as CNN Live and the David Letterman Show. She regards the media as a major source of English loanwords into the language. English is also the most widely studied foreign language in Germany (Hilgendorf 2007:140) and according to Hilgendorf (2007:141) «...evidence points to Germans having a positive and accommodating, even deferential, attitude towards English...»

Anglomania in Japan has been the subject of considerable study as well. There have even been proposals to make English an official language in Japan (Honna 2006:120), despite the fact that the level of English-Japanese bilingualism is very low in that country. Haarmann (1984:113) says that English is the foreign language with the highest level of prestige in Japan and he also remarks (p. 120) that commercials have been a particularly rich source of English loanwords. In a sociolinguistic analysis of English borrowings in Japanese advertising texts, Takashi (1990:327) claims that «the Japanese people usually associate English with something international and cosmopolitan...recent English words are borrowed not necessarily to fill a lexical gap, but to convey modernity and sophistication, particularly in the language of advertisements.» Although Seargeant (2005:315) considers the function of loanwords to be largely «ornamental», he 
acknowledges several studies showing that loanwords, notably from American English, are a «significant and ever-growing part of the Japanese lexicon». He also talks about concerted Ministry of Education initiatives, such as high school exchanges, to increase the knowledge of English in Japan.

\subsection{The identification of /s, z/ with correctness / prestige}

When L2 is considered prestigious by L1 speakers, native-like pronunciation may be targeted to the extent that speakers' abilities allow. In the case of $/ \theta, \delta /$, the L2 speaker's ability to correctly produce these difficult foreign consonants is more restricted. Evidence from several languages suggests that, in the absence of nativelike mastery of $/ \theta, \delta /$, their replacement by /s, $\mathrm{z} /$ is associated with greater prestige or correctness than replacement by $/ \mathrm{t}, \mathrm{d} /$. Consider the case of words containing $/ \theta, ठ /$ from Classical Arabic (CA); $\theta, \partial /$ are retained in some modern dialects (especially Bedouin), but in urban dialects they often split into /t, d/ and /s, z/. Replacement of the CA interdentals with /t, $\mathrm{d} /$ occurs in everyday words, while replacement by /s, z/ is used for words felt to have literary status, e.g. CA $\theta \bar{a} n \bar{l}$ 'second' > tāni but CA $\theta \bar{a} n a w \bar{l}$, an erudite word, > sānāwi 'secondary' (Carter 2001: 24). As a result of influences from CA and the variable treatment of interdentals, there exist in contemporary Egyptian Arabic many triplets, e.g. / $/$ a:li $:$ / / sa:lis/ /ta:lit/ 'third' (Schmidt 1987). However, alternation is not random; Schmidt demonstrates that different forms predominate in different speech styles: Stops do not occur in the most formal speech styles (word list reading and passage reading) and $/ \theta, \partial /$ do not occur in the least formal style (informal interview). Importantly for the present purpose is that the occurrence of /s, $\mathrm{z} /$ is higher in formal tasks and significantly lower in less formal tasks. According to Schmidt (1987:370) «stop pronunciations of words with etymological interdentals are universally identified by native speakers as colloquial and therefore «incorrect» when used in any context that normatively calls for the use of Classical Arabic.» Schmidt's research further provides strong confirmation that this attitude influences the treatment of English interdentals by Egyptian Arabic speakers of English L2: in more formal speech, the use of /s, $\mathrm{z} /$ is favored over $/ \mathrm{t}, \mathrm{d} /$.

In his description of the phonetics / phonology of various Arabic dialects, Cantineau (1960) had already noted the distinction between colloquial and educated speech with respect to the treatment of interdentals. He says explicitly (p. 282) that interdentals are normally adapted as dental stops except by some urban educated speakers who are borrowing from CA. According to Cantineau (p. 41), Old Arabic interdentals had begun to be adapted as stops long ago at the boundaries of Aramean areas. The change to stops was pervasive in nearly all non-nomadic dialects (p. 44), which suggests that this is the natural evolution of the interdentals (see also Ferguson 1978:419). The pronunciation/s, z/ is confined to pronunciations of learned loanwords from CA by educated people.

A study by Yildiz (2006) confirms the comparative naturalness of adaptation of $/ \theta /$ to $/ \mathrm{t} /$, rather than $/ \mathrm{s} /$. Using different tasks to investigate the acquisition of English interdentals by Turkish learners of English, Yildiz found that, in natural- 
istic speech, neither child nor adult Turkish learners of English produced /s/ for $/ \theta /$, while $/ \mathrm{t} / \mathrm{w}$ wa a frequent replacement in this task. The substitution of $/ \mathrm{s} /$ for $/ \theta /$ occurred only in a controlled speech task, where participants listened to words pronounced by a native English speaker and tried to mimic their pronunciation. The message is that when L2 speakers focus on speech form, they produce the target sounds, in this case, $/ \theta$ / correctly, or with an /s/ substitute, but when they are not focused on form, the spontaneous substitute for the interdental is $/ \mathrm{t} /$.

In section 3.1 we mentioned studies showing that Taiwanese and Chinese speakers of L2 English considered /s/ to be the best substitute for English / $\theta$ / when they could not produce it authentically. This reveals L2 speakers' awareness that $/ \theta$ / is difficult to pronounce and their awareness of different possible approximations for this difficult sound. The studies also show that learners place relative value on these possible approximations, even though they may not be in full control of which ones they spontaneously produce. Studies by Chang (2004) and Rau et al. (2009) are exceptional in that they address the value issue directly, but many other L2 studies confirm that the interdental is widely recognized to be difficult to pronounce and, by the fact that occurrence of /s/ is higher in controlled speech tasks than in spontaneous speech, they suggest that /s/ is a more highly valued substitute for the interdental than /t/ or /f/ for many ESL learners.

\section{Another flawed importation: the treatment of French $/ 3 /$ in Fula}

The Project CoPho loanword data suggest that $/ \theta$, $\mathrm{\delta}$ are not the only sounds subject to flawed importation in borrowing. This may also be true of the non-anterior fricative $/ 3 /$ in several French words borrowed in Fula, a language spoken in more than fifteen countries in West Africa. Due to the combined effect of two crosslinguistically common constraints, one against voiced fricatives (9a) and another against non-anterior fricatives (9b), this fricative is prohibited in Fula.

(9) Constraints on fricatives in Fula
a. no voiced fricatives $\left(*_{\mathrm{v}}, *_{\mathrm{z}}, *^{*}\right)$
b. no non-anterior fricatives $\left(* \int, * 3\right)$

The phonological adaptation is French / $3 />$ Fula /s/, exemplified in (10) $(62 / 70$, $88.6 \%$ of cases in the CoPho loanword database).

(10) Examples of French /3/ adapted to Fula /s/

\begin{tabular}{|c|c|c|c|c|}
\hline & French & & Fula & \\
\hline bagage & [bagaz] & $>$ & [bagaas] & 'luggage' \\
\hline bonjour & [bõzuR] & $>$ & [bonsuur] & 'hi, good day' \\
\hline je m'en fous & [3əmãfu] & $>$ & [samaafu] & 'I do not care' \\
\hline
\end{tabular}


However, in seven cases (7/70, 10\% of cases) the replacement for French $/ 3 /$ in Fula is $/ z /$, which is also prohibited in that language, due to constraint (9a). Examples of substitution of / $/ \mathrm{/}$ for French / 3 / are given in (11).

(11) Examples of French $/ 3 /$ resulting in $/ z /$ in Fula

\begin{tabular}{|c|c|c|c|c|}
\hline agence & $\begin{array}{l}\text { French } \\
\text { [azãs] }\end{array}$ & $>$ & $\begin{array}{l}\text { Fula } \\
\text { [azans] }\end{array}$ & 'press agency' \\
\hline bougie & [buzi] & $>$ & [buuzi] & 'candle' \\
\hline collège & [kol\&3] & $>$ & [kolecz] & 'high school' \\
\hline xygène & [oksizen] & $>$ & [oksizen] & 'oxygen' \\
\hline
\end{tabular}

We suggest that $/ \mathrm{z} /$ in these cases is a flawed importation of French $/ 3 /$. What is the rationale for this view? First, the rate at which /z/ (from /3/) occurs in Fula is $10 \%$, which corresponds roughly to the rate of importation of the other voiced fricatives of French, /z/ (4/46, 8.7\%) and /v/ (9/81, 11\%) in this language. Second, as with the interdentals in English, / $/ 3$ is a hallmark consonant of French, which is an official language of many countries in West Africa, and thus considered prestigious. For speakers who value French, importing voiced fricatives in loanwords, including /3/, may be important, although (and possibly because) it presents a challenge. Third, as in the case of interdentals $/ \theta, \partial /$, the non-anterior voiced fricative $/ 3 /$ is well known to be difficult to master, which is more likely to lead to unsuccessful importation. In sum, as in the case of the interdentals, three conditions obtain: the sound is difficult to articulate, it is typically associated with $\mathrm{L} 2$ and the $\mathrm{L} 2$ holds prestige.

Like the interdentals, $/ 3 /$ is a highly marked sound, according to three different criteria. First, though slightly more common cross-linguistically than the interdentals, /3/ is still typologically rare. In the UPSID database (Maddieson $1984)$, it occurs in only 51/317 languages $(16.1 \%)$. Second, this sound emerges late in L1 acquisition. Whether in English, French or Portuguese (languages for which such information is readily available), $/ 3 /$ is acquired late by L1 learners. Olmsted (1971) studied 100 children aged 15-54 months learning English as a first language, finding that $/ 3 /$, like the interdentals, is not reliably produced even by the middle of the fifth year. The late acquisition of English /3/ by native Englishspeaking children is backed up by other research as well (e.g. Snow 1963 and Bricker 1967).

Monnin and Lœvenbruck (2010) whose study bears on the acquisition of consonants in French and Drehu indicate that French and Drehu-speaking children, either bilingual or monolingual, acquire /3/ late compared to other consonants. MacLeod et al. (2011:98-99) who tracked the development of 156 monolingual Quebec French-speaking children ranging in age from 20-53 months address the late acquisition of $/ 3 /$ also in Quebec French. They report that, in initial position, $/ 3 /$ is acquired between $24-29$ months, in medial position, between $42-47$ months and, in final position, it is acquired between $48-53$ months. Overall, $/ 3 /$ is correctly produced by most Quebec French-speaking children in all word positions only in 
the 48-53 month age range, which is the last stage of phonological development and which is quite comparable to the age at which English-speaking children master it. Costa (2010), whose dissertation focuses on the acquisition of the consonantal system of European Portuguese by five children aged between one and five years, shows that $/ 3 /$ is among the last consonants acquired by Portuguese children as well. By the end of the study only the two oldest children could produce /3/. In sum, the acquisition evidence suggests that, as in the case of interdentals, cross-linguistic rarity of $/ 3 /$ is linked to its late acquisition, suggesting its articulatory difficulty relative to other consonant sounds.

The fricatives $/ \theta, \mathrm{d} /$ and $/ 3 /$ also have in common that they are generally lexically infrequent in the languages where they occur, which is a third indicator of markedness. Crystal (1995:242) reports that in adult spoken English, the frequency of $/ 3 /$ is about $0.1 \%$ ( $/ \theta /$ occurs with a frequency of only $.37 \%$ and $/ ð /$ with a higher frequency of $3.56 \%$, thanks only to its occurrence in function words, notably the, this that). In adult spoken French, the frequency of $/ 3 /$ is only $1.75 \%$ (Malécot 1974); in adult spoken Portuguese it is $1 \%$ (Costa 2010:30). In sum, /3/, like / $\theta$, $ð /$, is a marked sound; it stands out. For those seeking an authentic pronunciation, this makes it a target for importation. However, what makes it marked, and thus iconic, also makes it especially challenging for L2 learners of a language such as Fula. As in the case of $/ \theta, \delta /$, this can result in a flawed importation, in this case /z/.

\section{Conclusion}

As we have endeavored to show in this article, importations reflect the borrower's willingness to introduce an L2 phoneme into L1 because L2 is attractive / prestigious. Most importations are well performed, but phonemes that are particularly difficult to produce are susceptible to being ill-performed. We maintain that this is the case of the interdentals $/ \theta, \delta /$, as well as of the voiced non-anterior fricative /3/. Through the hypotheses in (2), we propose that the replacement of the interdentals by /s, z/ as seen in European French, German and Japanese is a case of flawed production-based importation, rather than phonological adaptation, which we claim would yield /t, $d /$. We have suggested that flawed importation is not due to perceptual confusion, which would result in /f, v/ but is, instead, a failure to fully master the articulation of the target sounds $/ \theta$, $\mathrm{d} /$. These sounds are crosslinguistically rare, late to emerge in L1 and L2 acquisition, and lexically infrequent in the languages where they occur. This is also true of $/ 3 /$.

In this article, we have attributed the ill-performed realization /s, z/ of interdentals to L2 prestige which it is often referred to as «anglomania» when it concerns English, and to educated speech when it concerns Arabic. However one might wonder if nowadays there is any country not «anglomaniac», given the pervasive influence of English through popular music, movies, internet, etc. and ask why not all countries import interdental or replace them with $/ \mathrm{s}, \mathrm{z} /$, instead of $/ \mathrm{t}, \mathrm{d} /$. We do not claim that all countries where English is prestigious will necessarily import interdentals either as is $(/ \theta, \partial /)$ or as flawed $(/ \mathrm{s}, \mathrm{z} /)$. What we do say is that the $/ \mathrm{s}$, $\mathrm{z} /$ realizations are motivated by the desire to import interdentals, and by the fact 
that these iconic phonemes, either from English or Classical Arabic, are difficult to produce. It is hard to predict precisely when an importation will occur, because as we indicated in section 4.2, attitude toward L2 is not the only factor that conditions importation. For instance a purist attitude toward L1 or a rebellious attitude toward L2 can be important impediments to importation. What we predict is that interdentals from a language that enjoys no particular prestige will not be imported as /s, z/. In such cases, interdentals will be adapted as /t, d/ or, if contact between the two languages is sufficiently intense and the L2 mastery sufficiently good, they will be imported as $/ \theta, \mathrm{d} /$, as in Macedonian, for example. ${ }^{6}$

Now, is this to say that the realization of interdentals as /s, $\mathrm{z} /$ is always crosslinguistically a case of flawed production-based importation rather than phonological adaptation? This is what our results suggest. At first glance, replacement by /s, $\mathrm{z} /$ or /t, d/ seems equally minimal in terms of number of processes; the first requires [strident] delinking and the second [+continuant] delinking. Nonetheless, the evidence that we have presented in this paper favors viewing adaptation to $/ t, d /$ as the decidedly preferred phonological option, if not the only one. The adaptation to /t, d/, whether from English, Greek, Classical Arabic or any other language with interdentals predominates far more than it should if adaptations to /s, z/ were equally principled phonologically. Also, /t, d/ are substitutes for the English interdentals in many dialects of English, while /s, z/ almost never are.

Finally, we would like to point out that this asymmetry is not linked to any particular theoretical orientation. For example, in an Optimality Theory (OT) analysis where it could a priori be assumed that European French, German and Japanese simply override /t, d/ (i.e. the constraint against /s, z/ is lower ranked in these languages than in those adapting interdentals to /t, $d /$ ), the important link that we find between prestige and the substitution of interdentals by /s, z/ in loanword adaptation and in L2 acquisition would still have to be made. Given the freedom that languages have to rank constraints in the OT framework, the fact that so few languages choose the /s, z/ option - and even when they do, they do not do it exclusively as shown in the table in (4) - would also call for an explanation if the adaptation of the interdentals to $/ \mathrm{t}, \mathrm{d} /$ and /s, $\mathrm{z} /$ were equally justified phonologically. Both realizations should occur as frequently in native as well as in borrowed words. As shown in this article, this is not verified. This is why we think the notion of ill-performed importations is relevant to any theoretical phonological framework.

6. One reviewer suggested that it would be interesting to study the adaptation of interdentals from different foreign languages to see if they follow different patterns, according to the status of the source language for the borrowing language. For example, it was suggested that we compare the adaptation of Greek vs. English interdentals into German. While theoretically interesting, such a scenario is not as easily handled as it might first appear. First, we need a reasonable number of data from both source languages, not just one, to make a valid comparison. This is not easy, particularly for sounds as lexically infrequent as interdentals. Second, extraneous factors, such as the period of borrowing (ancient vs. recent) or the status of the borrowings (learned vs. colloquial) might be responsible for possible different patterns of adaptation. This said, if these problems and other possible external factors can be controlled, we agree that this would be an ideal test of our hypothesis. 
We suggest that the phonological explanation for choosing the adaptation to /t, d/ instead of /s, z/ lies beyond the notion of minimality (which requires as few processes as possible applying at the lowest representational level to which the constraint refers; e.g. Paradis and LaCharité 1997, 2001). While minimality is a necessary condition on the adaptation of foreign sounds, newly emerging evidence suggests that it may not be the only phonological consideration. Stoltzfus (2011, in preparation) shows that the determining factor for selecting among possible minimal adaptations is generally markedness. In other words, it seems that adaptations strongly tend to reduce phoneme complexity. He also shows that when a minimal adaptation available in L1 would result in even more complexity, then, importation of the foreign segment occurs significantly more often than it would otherwise. In the case at hand, delinking [+continuant] results in the stops $/ t, d /$, a type of consonant typologically less marked than the fricatives /s, z/ that would be generated by delinking [strident]. This markedness avenue is certainly promising but will obviously require more investigation that we must leave for future research.

\section{References}

Abu-Manga, Al Amin (1986). Fulfulde in the Sudan: Process of Adaptation to Arabic. Berlin: Verlag von Dietrich Reimer.

Anisman, Paul (1975). «Some Aspects of Code Switching in New York Puerto Rican English». Bilingual Review 2: 56-85.

Ball, Martin; Rahilly, Joan (1999). Phonetics: the Science of Speech. London: Arnold.

Bell, Alan (2006). «Style and Linguistic Repertoire». In: Llamas, Carmen; Mullany, Louise; Stockwell, Peter (eds.). The Routledge Companion to Sociolinguistics. London: Routledge, pp. 95-100.

Bhatia, Tej (2006). «World Englishes in Global Advertising». In: Kachru, Braj; Kachru, Yamuna; Nelson, Cecil (eds.). The Handbook of World Englishes. Malden, Mass.: Blackwell Publishing, pp. 601-619.

Bolduc, Élyse (2001). Nativisation phonologique d'emprunts anglais en espagnol mexicain. Laval University, M.A. thesis.

Boly, Joseph (1974). Chasse aux anglicismes: Petit Glossaire franglais-français. Brussels: Louis Musin Éditeur.

Bouchard, Chantal (1999). On n'emprunte qu'aux riches: La valeur sociolinguistique et symbolique des emprunts. St. Laurent, Quebec: Les Editions Fides.

Brannen, Kathleen (2002). «The Role of Perception in Differential Substitution». Canadian Journal of Linguistics 47(1/2): 1-46.

Bricker, William A. (1967). «Errors in the Echoic Behavior of Preschool Children». Journal of Speech and Hearing Research 10: 67-76.

Bowen, Caroline (1998). «Typical Speech Development: The Gradual Acquisition of the Speech Sound System». Retrieved from http://www.speech-language-therapy. com/acquisition.html.

Canepari, Luciano (2010). The Pronunciation of English around the World. Munich: Lincom Europa.

Cantineau, Jean (1960). Études de linguistique arabe. Paris: Klincksieck. 
Carter, Michael (2001). «Arabic». In: Garry, Jane; Rubino, Carl (eds.). Facts about the World's Languages: An Encyclopedia of the World's Major Languages, Past and Present. New York: The H.W. Wilson Company, pp. 23-27.

Cassidy, Frederick; LePage, Robert (1980). Dictionary of Jamaican English. Cambridge: Cambridge University Press.

Chang, Hui-Huan Ann (2004). Phonological Variation of (th) among EFL Learners in Taiwan, Providence University, M.A. thesis.

Childs, Becky; De Decker, Paul; Deal, Rachel; Kendall, Tyler; Thorburn, Jennifer; Williamson, Maia; Van Herk, Gerard (2010). «Stop Signs: The Intersection of Interdental Fricatives and Identity in Newfoundland». University of Pennsylvania Working Papers in Linguistics 16(2): 26-35.

Cofer, T. (1972). Linguistic Variability in a Philadelphia Speech Community. University of Pennsylvania, doctoral dissertation.

da Costa, Teresa (2010). The Acquisition of the Consonantal System in European Portuguese: Focus on Place and Manner Features. University of Lisbon, doctoral dissertation.

Crystal, David (1995). The Cambridge Encyclopedia of the English Language. Cambridge: Cambridge University Press.

Diallo, Abdourahmane (1992). Étude de l'intégration morphologique et phonologique des emprunts linguistiques arabes en pulaar de Guinée. Mohamed University, doctoral dissertation.

Dodd, Barbara: Holm, Alison; Hua, Zhu; Crosbie, Sharon (2003). «Phonological Development: A Normative Study of British English-speaking Children». Clinical Linguistics and Phonetics 18(8): 618-643.

Dowd, Janice; Zuengler, Jane; Berkowitz, Diana (1990). «L2 Social Marking: Research Issues». Applied Linguistics 11(1): 16-29.

Dyer, Judy (2006). «Language and Identity». In: Llamas, Carmen; Mullany, Louise; Stockwell, Peter (eds.). The Routledge Companion to Sociolinguistics. London: Routledge, pp. 101-108.

Eckert, Penelope (2000). Linguistic Variation as Social Practice. Oxford: Blackwell. Étiemble, René (1973). Parlez-vous franglais? Paris: Gallimard.

Fecteau, Shirley (1998). Adaptations et importations: Le comportement des segments et des patrons accentuels anglais en espagnol mexicain. Laval University, M.A. thesis.

Ferguson, Charles (1978). «Phonological Processes». In: Greenberg, Joseph (ed.). Universals of Human Language. Stanford: Stanford University Press, pp. 403-442.

Fouché, Pierre (1959). Traité de la pronunciation française. Paris: Klincksieck.

Friedman, Victor (2008). «Macedonian Dialectology and Eurology: Areal and Typological perspectives». Sprachtyplogie und Universalienforschung 61(2): 139-146.

Fu, Jo Shan (2010). A Comparison between Taiwanese ESL Learners' Perception and Production of English Sounds. Southern Illinois University at Carbondale, doctoral dissertation.

Garrett, Peter (2006). «Language Attitudes». In: Llamas, Carmen; Mullany, Louise; Stockwell, Peter (eds.). The Routledge Companion to Sociolinguistics. London: Routledge, pp. 116-121.

Gatbonton, Elizabeth; Trofimovich, Pavel (2008). «The Ethnic Group Affiliation and L2 Proficiency Link: Empirical Evidence». Language Awareness 17(3): 229-248. 
Gatbonton, Elizabeth; Trofimovich, Pavel; Magid, Michael (2005). «Learners’ Ethnic Group Affiliation and L2 Pronunciation Accuracy: A Sociolinguistic Investigation». TESOL Quarterly 39(3): 489-511.

Gerritsen, Johan (1982). «English Influence on Dutch». In: Filipovic, Rudolf (ed.). The English Element in European Languages. Vol. 2. Reports and Studies. Zagreb: Institute of Linguistics, University of Zagreb, pp. 154-179.

Gonet, Wiktor; Pietron, Grzegorz (2006). «English Interdental Fricatives in the Speech of Polish Learners of English». Neofilologia VIII: 73-93.

Goulet, Marie Josée (2001). L'adaptation phonologique d'emprunts lexicaux anglais en japonais et la faible influence de la graphie. Laval University, M.A. thesis.

Grosjean, Francois (1982). Life with Two Languages: In Introduction to Bilingualism. Cambridge, Mass.: Harvard University Press.

Haarmann, Harald (1984). «The role of Ethnocultural Stereotypes and Foreign Languages in Japanese Commercials». International Journal of the Sociology of Language 50: 101-121.

Hancin-Bhatt, Barbara Jean (1994). Phonological Transfer in Second Language Perception and Production. University of Illinois, doctoral dissertation.

Harriott, Phillip; Cichocki, Wladyslaw (1993). «Accentedness ratings of English Loanwords by Acadian French Listeners». Revue québequoise de linguistique 22(2): 93-106.

Hartford, Beverly (1978). «Phonological Differences in the English of Adolescent Female and Male Mexican-Americans». International Journal of the Sociology of Language 17: 55-64.

Haugen, Einar (1956). Bilingualism in America: A Bibliography and Research Guide. Alabama: University of Alabama Press.

Henninger, Thomas (1990). «The Greek Layer in the Bulgarian Literary Language: Some Balkan Elements of the Vocabulary during the National Revival». The Slavonic and East European Review 68(4): 601-615.

Hilgendorf, Suzanne (1996). «The Impact of English in Germany». English Today 12(3): 3-14.

Hilgendorf, Suzanne (2007). «English in Germany: Contact, Spread and Attitudes». World Englishes 26(2): 131-148.

Holm, John (1989). Pidgins and Creoles: A Reference Survey. Cambridge, Mass.: Cambridge University Press.

Honna, Nobuyuki (2006). «East Asian Englishes». In: Kachru, Braj; Kachru, Yamuna; Nelson, Cecil (eds.). The Handbook of World Englishes. Malden, Mass.: Blackwell Publishing, pp. 114-129.

Hooke, Richard; Rowell, Geoffrey (1982). A Handbook of English Pronunciation. London: Edward Arnold.

Hyman, Larry (1970). «The Role of Borrowings in the Justification of Phonological Grammars». Studies in African Linguistics 1: 1-48.

Jakobs-Németh, Ilona (1982). «Phonological Adaptation of English Loanwords in Hungarian». In: Filipovic, Rudolf (ed.). The English Element in European Languages. Vol. 2. Reports and Studies. Zagreb: Institute of Linguistics, University of Zagreb, pp. 244-265.

Joseph, Brian (2009). «Broad vs. Localistic Dialectology, Standard vs. Dialect: The Case of the Balkans and the Drawing of Linguistic Boundaries». In: Tsiplakon, 
Stavroula; Karyolemou, Marilena; Pavlou, Pavlos (eds.). Language Variation European Perspectives II: Selected Papers from the 4th International Conference on Language Variation in Europe. Philadelphia, Penn.: John Benjamins Publishing Company, pp. 119-134.

Kelly-Holmes, Helen (2000). «Bier, Parfum, Kaas: Language Fetish in European Advertising». European Journal of Cultural Studies 3(1): 67-82.

Kenworthy, Joanne (1987). Teaching English Pronunciation. London: Longman.

Labatut, Roger (1983). «Les emprunts du peul à l'arabe». Langue arabe et langues africaines. Paris: CILF, pp. 41-70.

Labov, William (1966). The Social Stratification of English in New York City. Washington: Center for Applied Linguistics.

LaCharité, Darlene; Paradis, Carole (2005). «Category Preservation and Proximity versus Phonetic Approximation in Loanword Adaptation». Linguistic Inquiry 36(2): 223-258.

Ladefoged, Peter; Maddieson, Ian (1996). The Sounds of the World's Languages. Oxford, U.K.: Blackwell Publishers.

Leslau, Wolf (1990). Arabic Loanwords in Ethiopian Semitic. Wiesbaden: Otto Harrassowitz.

Lombardi, Linda (2003). «Second Language Data and Constraints on Manner: Explaining Substitutions for the English Interdentals». Second Language Research 19: 225-250.

Lukaszewicz, Katarzyna (2009). Acquisition of English Dental Fricatives by Polish Learners of ESL. University of Essex, M.A. thesis.

MacKay, Ian (1987). Phonetics: The Science of Speech Production. Boston: Allyn and Bacon.

Mackey, William (1992). «La genèse d'une typologie de la diglossie». Langues et linguistique (special issue: Hommage à William Mackey), 31-43.

MacLeod, Andrea; Sutton, Ann; Trudeau, Natasha; Thordardottir, Elin (2011). «The Acquisition of Consonants in Québécois French: A Cross-Sectional Study of PreSchool Aged Children». International Journal of Speech-Language Pathology 13(2): 93-109.

Maddieson, Ian (1984). Patterns of Sounds. Cambridge, U.K.: Cambridge University Press.

Maddieson, Ian (1997). «Phonetic Universals». In: Hardcastle, William; Laver, John (eds.). The Handbook of Phonetic Sciences. Oxford, U.K.: Blackwell, pp. 619-639.

Malécot, André (1974). «Frequency of Occurrence of French Phonemes and Consonant Clusters». Phonetica 29: 158-170.

Martin, Elizabeth (1998). Code-Mixing and Imaging of America in France: The Genre of Advertising. University of Illinois at Urbana-Champagne, doctoral dissertation.

Martin, Elizabeth (1999). «The Politics of English in France: Creative Strategies for Using English in French Television Commercials Despite Legal Restrictions». Paper presented at the Fifth International conference on World Englishes, University of Illinois.

Martin, Elizabeth (2006). «World Englishes in the Media». In: Kachru, Braj; Kachru, Yamuna; Nelson, Cecil (eds.). The Handbook of World Englishes. Malden, Mass.: Blackwell Publishing, pp. 583-600.

Martin, Elizabeth (2008). «Language-Mixing in French Print Advertising». Journal of Creative Communications 3(1): 49-76. 
Miller, George; Nicely, Patricia (1955). «An Analysis of Perceptual Confusion Among Some English Consonants». Journal of the Acoustical Society of America 27: 2.

Milroy, James (2006). «The Ideology of the Standard Language». In: Llamas, Carmen; Mullany, Louise; Stockwell, Peter (eds.). The Routledge Companion to Sociolinguistics. London: Routledge, pp. 133-139.

Monnin, Julia; Lœvenbruck, Hélène (2010). «Specificités de l'acquisition des consonnes en français et en drehu: Influence de la langue ambiante». XXXVIIIèmes Journées d'Études sur la Parole. Mons, Belgium.

Mowrer, Donald; Sundstrom, Patricia (1988). «Acquisition of /s/ among Kindergarten Children who Misarticulate /s/ as Measured by the Deep Test of Articulation». Journal of Communication Disorders 21: 177-187.

Olmsted, David (1971). Out of the Mouth of Babes. The Hague: Mouton.

Orešnik, Birgitta (1982). «On the Adaptation of English Loanwords into Finnish». In: Filipovic, Rudolf (ed.). The English Element in European Languages. Vol. 2. Reports and Studies. Zagreb: Institute of Linguistics, University of Zagreb, pp. 180-212.

Pandey, Anjali (1997). Articulating Prejudice: A Linguistic Perspective on Animated Movies. University of Illinois at Urbana-Champagne, doctoral dissertation.

Papazisovska, Vangelica (1966). «Grckite zaemki I nivnata adaptacija vo make». Makedonski Jazik 27: 159-168.

Paradis, Carole; LaCharité; Darlene (1997). «Preservation and Minimality in Loanword Adaptation». Journal of Linguistics 33(2): 379-430.

Paradis, Carole; LaCharité; Darlene (2001). «Guttural Deletion in Loanwords». Phonology 18(2): 255-300.

Paradis, Carole; LaCharité; Darlene (2008). «Apparent Phonetic Approximation: English Loanwords in Old Quebec French». Journal of Linguistics 44: 87-128.

Paradis, Carole; Lebel, Caroline; LaCharité, Darlene (1993). «Adaptation d'emprunts: les conditions de la préservation segmentale». In: Dyck, Carrie (ed.). Actes de l'ACL congrès annuel. Toronto, Toronto Working Papers in Linguistics, pp. 461-476.

Picard, Marc (2002). «The Differential Substitution of English / $\theta$ б/ in French: The Case against Underspecification in L2 Phonology». Lingvisticae Investiationes 25(1): 87-96.

Pickett, James (1999). The Acoustics of Speech Communication: Fundamentals, Speech Perception Theory, and Technology. Boston: Allyn and Bacon.

Piller, Ingrid (2003). «Advertising as a Site of Language Contact». Annual Review of Applied Linguistics 23: 170-183.

Poldauf, Ivan (1982). «Phonological Aspects of the Adoption of English Words by Czech». In: Filipovic, Rudolf (ed.). The English Element in European Languages. Vol. 2. Reports and Studies. Zagreb: Institute of Linguistics, University of Zagreb, pp. 57-70.

Rau, Victoria; Chang, Hui-Huan Ann; Tarone, Elaine (2009). «Think or Sink: Chinese Learners' Acquisition of the Voiceless Interdental Fricative». Language Learning 59(3): 581-621.

Rogers, Henry (2000). The Sounds of Language: An Introduction to Phonetics. Essex, U.K.: Pearson Education Limited.

Roy, Marie-Josée (1992). Le rôle des contraintes phonologiques dans l'adaptation d'emprunts anglais en français québécois. Laval University, M.A. thesis. 
Savard, Mélanie (2007). Nativisation phonologique et importations dans les emprunts anglais nord-américains et italien calabrais: données statistiques et implications théoriques. Laval University, doctoral dissertation.

Schmidt, Richard (1987). «Sociolinguistic Variation and Language Transfer in Phonology». In: Ioup, Georgette; Weinberger, Steven (eds.). Interlanguage Phonology: The Acquisition of a Second Language Sound System. New York: Newbury House, pp. 365-377.

Schmieger, Roland (1998). «The Situation of the Macedonian Language in Greece: Sociolinguistic Analysis». International Journal of the Sociology of Language 131: 125-155.

Seargeant, Philip (2005). «Globalisation and Reconfigured English in Japan». World Englishes 24(3): 309-319.

Segalowicz, Norman; Gatbonton, Elizabeth; Trofimovich, Pavel (2008). «Links between Ethnolinguistic Affiliation, Self-Related Motivation and Second Language Fluency: Are they Mediated by Psycholinguistic Variables?». In: Dornyei, Zoltan; Ushioda, Ema (eds.). Motivation, Language Identity and the L2 Self. Bristol, U.K.: Multilingual Matters, pp. 172-192.

Smit, Ann; Hand, Linda; Freilinger, Joseph; Bernthal, John; Bird, Ann (1990). «The Iowa Articulation Norms Project and its Nebraska Replication». Journal of Speech and Hearing Disorders 55: 779-798.

Snow, Katherine (1963). «A Detailed Analysis of Articulation Responses of 'Normal' First Grade Children». Journal of Speech and Hearing Research 6: 277-290.

Sørensen, Knud (1982). «English Influence on Contemporary Danish». In: Filipovic, Rudolf (ed.). The English Element in European Languages. Vol. 2. Reports and Studies. Zagreb: Institute of Linguistics, University of Zagreb, pp. 71-153.

Stoltzfus, Daniel (2011). «Complexity Reduction vs. Manner Feature Relience in Loanword Adaptation». In: Armstrong, Lisa (ed.). $29^{\text {th }}$ Canadian Linguistic Association Proceedings, pp. 1-15. Published on line.

Stoltzfus, Daniel (in preparation). Predictions on Markedness and Feature Resilience in the Adaptation of Loanwords. Laval University, doctoral dissertation.

Takashi, Kyoko (1990). «A Sociolinguistic Analysis of English Borrowings in Japanese Advertising Texts». World Englishes 9(3): 327-341.

Tinelli, Henri (1981). Creole Phonology. The Hague: Mouton Publishers.

Tournier, Jean (1998). Les mots anglais du français. Paris: Les Éditions Belin.

Trofimovich, Pavel; Gatbonton, Elizabeth; Segalowitz, Norman (2007). «A Dynamic Look at L2 Phonological Learning: Seeking Processing Explanations for Implicational Phenomena». Studies in Second Language Acquisition 29: 407-448.

Vance, Timothy (1987). An Introduction to Japanese Phonology. Albany, New York: State University of New York Press.

Velčić, Ivana (1982). «The English Element in Croation Sports Vocabulary». In: Filipovic, Rudolf (ed.). The English Element in European Languages. Vol. 2. Reports and Studies. Zagreb: Institute of Linguistics, University of Zagreb, pp. 421-438.

Vilke, Mirjana (1982). «The English Element in Serbo-Croation Technical Vocabulary». In: Filipovic, Rudolf (ed.). The English Element in European Languages. Vol. 2. Reports and Studies. Zagreb: Institute of Linguistics, University of Zagreb, pp. 439-467. 
Voirol, Michel (1993). Anglicismes et anglomanie. Paris: Éditions du Centre de formation et de perfectionnement des journalists.

Wells, John C. (1982). Accents of English I: An Introduction. Cambridge, U.K.: Cambridge University Press.

Weinreich, Uriel (1968). Languages in Contact: Findings and Problems. The Hague: Mouton.

Winitz, Harris (1969). Articulatory Acquisition and Behavior. New York: AppletonCentury-Crofts.

Wolfram, Walt (1969). A Linguistic Description of Detroit Negro Speech. Washington: Center for Applied Linguistics.

Wolfram, Walt; Schilling-Estes, Nathalie (1998). American English. Oxford: Blackwell Publishers.

Yildiz, Yasemin (2006). «The Acquisition of English Interdentals by Turkish Learners: Explaining Age Effects in L2 Phonology». Essex Graduate Student Papers in Language and Linguistics 8: 144-165.

Zuengler, Jane (1988). «Identity Markers and L2 Pronunciation». Studies in Second Language Acquisition 10: 33-49. 